\title{
Cranberry Nutrient Management in Southeastern Massachusetts: Balancing Crop Production Needs and Water Quality
}

\author{
Carolyn DeMoranville ${ }^{1}$
}

ADDITIONAL INDEX WORDs. Vaccinium macrocarpon, nitrogen, phosphorus, total maximum daily load

\begin{abstract}
SUMMARY. The american cranberry (Vaccinium macrocarpon) is a wetland plant native to North America. The plant is adapted to sandy, nutrient-poor, low $\mathrm{pH}$ soils and thus, like blueberry (Vaccinium sp.), its nutritional requirements are low compared with many other perennial fruit crops. Research conducted over the past 30 years has defined the annual requirements for nitrogen $[\mathrm{N}(20-60 \mathrm{lb} / \mathrm{acre})]$, phosphorus $[\mathrm{P}(<20 \mathrm{lb} / \mathrm{acre})]$, and potassium (40-120 lb/acre) based on tissue testing, plant growth demands, potential for remobilization, and determination of removal in the crop. These three nutrient elements are those most commonly applied to the crop in fertilizers. However, much of the work on nutrient rate requirements was conducted on native cultivars and there is an expectation that requirements of newer hybrid cultivars are greater. In Massachusetts, cranberries are grown in coastal watersheds and often depend on small lakes as their water source for irrigation, harvest, and winter flooding. Since cranberry production is heavily dependent on water use, the interaction of nutrient management and water management has become a primary focus area for research and extension, particularly for $\mathbf{N}$ and $\mathbf{P}$, the nutrient elements most frequently associated with environmental pollution. Recent preliminary research examining cranberry farms with varied configurations (e.g., water passes through the bog and exits via a long channel, water recirculates back into the supply water body) has indicated that the cranberry bogs may act as either a source or sink for $\mathrm{N}$ depending on configuration and management activities. In a study of cranberry farms where $P$ use was reduced to an average of $<10 \mathrm{lb} /$ acre, $P$ concentration in harvest flood water declined by as much as $85 \%$ while crop production was sustained. Site variation in output of $\mathrm{N}$ and $P$ in cranberry drainage and flood waters indicates the need for further research into the variables that control these processes, including soil types, site hydrology, nutrient application rates and forms, and water-management activities.
\end{abstract}

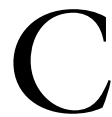

ranberry is a low-growing perennial plant that produces stolons that cover the soil and roots at intervals along the stolon length. Vertical shoots (uprights) from the stolon bear the crop. Native to North America, the plant is currently primarily cultivated in northern coastal areas in the United States (Massachusetts, New Jersey, Oregon, and Washington) and Canada (Maritime Provinces and British Columbia), as well as in central regions (Wisconsin and Quebec). In 2014, cranberries were produced on 40,500 acres in the United States with Massachusetts producing $27.7 \%$ of the national crop on
$30.6 \%$ of the acreage (U.S. Department of Agriculture, 2015).

Nutrient management for cranberries in Massachusetts is not different from that in other crops: support of crop production requires application of nutrients in forms that the plant can use, in amounts that supply plant needs, and at a time when the plant can take up and use the nutrients. However, cranberry is a wetland plant, and its commercial cultivation in Massachusetts takes place in converted (before prohibition by regulation) and manufactured wetlands. In Massachusetts, cranberries are grown in coastal watersheds and often depend on small lakes as their water source for irrigation, harvest, and winter flooding. Some of the lakes and estuaries of these watersheds are included in the state's list of impaired water bodies due to $\mathrm{P}$ (inland lakes) or $\mathrm{N}$ (estuaries) enrichment. Under the Federal Clean Water Act, all listed waters must have total maximum daily load (TMDL) limits set. The TMDL process identifies the acceptable load and divides it among the lands that drain into the water body. When cranberry farms are within the regulated area for a TMDL, even if cranberry farming is not the major contributor to the nutrient pollution, a limit is set on the amount of $\mathrm{N}$ or $\mathrm{P}$ that can leave the farm and move into the impaired water body. Therefore, in addition to considerations of crop need, nutrient management, particularly that for $\mathrm{N}$ and $\mathrm{P}$, must include consideration of environmental protection and the potential of water management practices to move nutrients off the farm.

The purpose of this article is to review recent information regarding nutrient requirements of cranberry and recommendations for the use of $\mathrm{N}, \mathrm{P}$, and potassium $(\mathrm{K})$, the three nutrient elements most commonly applied to the crop. The article then continues with a discussion of water management and water quality as it relates to the management of $\mathrm{N}$ and $\mathrm{P}$, the two nutrient elements most often implicated in degradation of coastal and inland waters in Massachusetts.

\section{Nutrient requirements and recommendations}

Cranberry is an acid-loving plant, adapted to sandy, hydric, nutrientpoor soils. This is reflected in the low concentrations of nutrient elements in cranberry leaf tissues (Davenport et al., 1995). The concentration of $\mathrm{N}$ in cranberry leaf tissue is low when compared with other fruit crops (Table 1), while only blueberry is similar to cranberry in its low leaf $\mathrm{K}$ concentration. In
UMass Amherst Cranberry Station, One State Bog Road, East Wareham, MA 02538

This paper was part of the colloquium, "Recent Advances in Perennial Berry Crop Nutrition and Directions for Future Research," held 28 July 2014 at the ASHS Annual Conference, Orlando, FL, and sponsored by the Viticulture and Small Fruit Working Group.

${ }^{1}$ Corresponding author. E-mail: carolynd@umass.edu.

\begin{tabular}{llll}
\hline $\begin{array}{l}\text { Units } \\
\text { To convert U.S. to SI, } \\
\text { multiply by }\end{array}$ & U.S. unit & SI unit & $\begin{array}{l}\text { To convert SI to U.S., } \\
\text { multiply by }\end{array}$ \\
\hline 0.4047 & $\mathrm{acre}(\mathrm{s})$ & $\mathrm{ha}$ & 2.4711 \\
1233.4819 & $\mathrm{acre}-\mathrm{ft}$ & $\mathrm{m}^{3}$ & 0.0008 \\
0.4536 & $\mathrm{lb}$ & $\mathrm{kg}$ & 2.2046 \\
1.1209 & $\mathrm{lb} / \mathrm{acre}$ & $\mathrm{kg} \cdot \mathrm{ha}^{-1}$ & 0.8922 \\
1 & $\mathrm{ppm}$ & $\mathrm{mg} \cdot \mathrm{L}^{-1}$ & 1
\end{tabular}

Hortlechnology $\cdot$ August 2015 25(4) 
Table 1. Comparison of leaf nutrient critical concentrations (percent dry weight) of nitrogen (N), phosphorus (P), and potassium (K) among several fruit crops.

\begin{tabular}{|c|c|c|c|c|c|}
\hline Crop & Species & Reference & $\mathbf{N}(\%)$ & $\mathbf{P}(\%)$ & K (\%) \\
\hline Cranberry & Vaccinium macrocarpon & Davenport et al., 1995 & $0.9-1.1$ & $0.10-0.20$ & $0.40-0.75$ \\
\hline Blueberry, lowbush & Vaccinium angustifolium & Yarborough and Smagula, 2013 & $1.6-1.9$ & $0.11-0.14$ & $0.31-0.56$ \\
\hline Blueberry, highbush & Vaccinium corymbosum & Strik, 2013 & $1.7-2.0$ & $0.11-0.40$ & $0.41-0.70$ \\
\hline Strawberry, Oregon & Fragaria $\times$ ananassa & Strik, 2013 & $2.5-3.0$ & $0.15-0.30$ & $1.0-2.0$ \\
\hline Grape, bloom & Vitis vinifera & Davenport and Horneck, 2011 & $2.5-3.5$ & $0.15-0.45$ & $0.75-1.5$ \\
\hline Apple & Malus $\times$ domestica & Hanson, 2014 & $2.0-2.6$ & $0.16-0.30$ & $1.3-1.5$ \\
\hline
\end{tabular}

contrast, cranberry leaf $\mathrm{P}$ concentration is similar to that in many small and tree fruit crops.

Nutrient removal by 'Early Black', the native cranberry cultivar most commonly planted in Massachusetts, was calculated based on nutrient concentrations in the leaves and fruits (DeMoranville, 1992). For a crop load of 200 barrels $/$ acre $(1 \mathrm{barrel}=100 \mathrm{lb}$ ), including the associated leaf and stem debris removed during water harvest operations, the calculated values were: $23.6 \mathrm{lb} /$ acre $\mathrm{N}, 4.2$ $\mathrm{lb} /$ acre $\mathrm{P}$, and $20.8 \mathrm{lb} /$ acre K. Since the newest hybrid cranberry cultivars can produce crops of 600 barrels/ acre or greater and have a greater vegetative biomass compared with native cultivars, their annual nutrient removal and thus their nutrient requirements are expected to be substantially greater. However, no replicated field research has confirmed that expectation.

Nitrogen fertilization has been extensively studied in native cranberry cultivars and first-generation hybrids (Davenport, 1996; Davenport and Vorsa, 1999; DeMoranville, 1992; Hart et al., 1990). Native cultivars and the most common hybrid, Stevens, all showed either a linear negative or a quadratic (increasing then decreasing after reaching a peak) yield response to increasing $\mathrm{N}$ fertilizer additions. These same cultivars showed a positive linear response in upright and stolon growth (vegetative biomass production) with increasing $\mathrm{N}$. However, Davenport and Vorsa (1999) observed that some first-generation hybrids showed little positive or negative yield or vegetative response to increasing $\mathrm{N}$ fertilizer rates. The newest hybrid releases from Rutgers University show little or no negative vegetative response to increasing $\mathrm{N}$ rate (N. Vorsa, personal communication). These cultivars increase in fruit yield as $\mathrm{N}$ application rate is increased but do not produce excess vegetative tissue that could have negative consequences in the production system (e.g., interfere with harvest equipment; provide conditions favoring fungal infections).

A common observation in $\mathrm{N}$ fertilizer field trials in cranberry has been the lack of any $\mathrm{N}$ response in the first year of applications. In a study of 30 Massachusetts cranberry sites, N rate in the crop year correlated with yield less than $20 \%$ of the time (C. DeMoranville and J.R. Davenport, unpublished data). However, applied $\mathrm{N}$ rate in the year before the crop $(r=$ $0.4)$ and 2 years before $(r=0.5)$ was positively correlated with yield for all of the years studied.

The N-response field trial outcomes and calculated $\mathrm{N}$ used in biomass and crop production have been used as the basis for the development of the current extension recommendations for $\mathrm{N}$ fertilizer rates in cranberry production (Davenport et al., 2000; DeMoranville, 2014a; Hart et al., 2015). Because of the multiple year correlations, wide swings in $\mathrm{N}$ application rates from year to year are not recommended. Rather, growers are encouraged to make small adjustments to the base rates recommended for cultivars and soil types. Those changes should be based on observation of the plant growth and color, presence of factors that impact yield potential (e.g., frost injury, pest infestations), and results of previous year tissue tests. Current base $\mathrm{N}$ rate recommendations are 20-60 lb/acre in Massachusetts, $40 \mathrm{lb} /$ acre in Wisconsin, and 40-60 lb/acre in Oregon and Quebec. In 1998, most Oregon and Wisconsin production was from hybrid cultivars $(>80 \%$ and $>55 \%$, respectively) while almost $80 \%$ of Massachusetts acreage remained planted in native selections (Roper, 1999). By 2011, Wisconsin hybrid acreage had increased substantially, Quebec had expanded production, primarily of the cultivar Stevens, but $>60 \%$ of Massachusetts production remained in native cultivars (J. DeVerna, personal communication). In Massachusetts, $\mathrm{P}$ and $\mathrm{K}$ are often applied to cranberries with $\mathrm{N}$ in "complete" $\mathrm{N}-\mathrm{P}-\mathrm{K}$ fertilizers. The applied rate of the $\mathrm{N}-\mathrm{P}-\mathrm{K}$ fertilizer is then based on the desired $\mathrm{N}$ rate. The ratios of $\mathrm{P}$ and $\mathrm{K}$ to $\mathrm{N}$ in the fertilizer must therefore be chosen based on the desired rate of $\mathrm{P}$ and $\mathrm{K}$ that will be delivered at that applied $\mathrm{N}$ rate.

Other than $\mathrm{N}, \mathrm{K}$ is the element required in the greatest amount to support cranberry vegetative biomass and fruit production, yet it has been much less studied compared with $\mathrm{N}$ and $\mathrm{P}$. Additions of $\mathrm{K}$ fertilizer have been shown to increase $\mathrm{K}$ concentration in cranberry leaf tissue (Eaton, 1971; Eaton and Meehan, 1976), often beyond what is considered the sufficient range (Davenport et al., 1995 ). In a 2 -year study on two soil types in Wisconsin, Roper (2009) found no increase in yield at any rate of applied K, and attributed the outcome to sufficient $\mathrm{K}$ in the cranberry leaf tissue, even in the untreated controls. However, yield decline on beds receiving more than $600 \mathrm{lb} /$ acre $\mathrm{K}$ has been observed (T. Roper, personal communication), possibly due to a "salt effect" (i.e., increase in soil electrical conductivity (EC) due to the fertilizer addition). In column studies (Roper, 2009), high rates of applied $\mathrm{K}$ increased EC of the soil solution to levels considered detrimental to cranberry. Current recommendations (DeMoranville, 2014a) derived from crop removal calculations and field observations are for annual applications of 40-120 lb/ acre $\mathrm{K}$, adjusted based on soil and tissue test results.

In addition to $\mathrm{N}$ and $\mathrm{K}$, most Massachusetts cranberry beds receive annual applications of $\mathrm{P}$. In the highly 
acid soils of these beds, generally of $\mathrm{pH}$ between 4.0 and 5.0 (DeMoranville, 2008a), any free phosphate is readily bound to iron and aluminum. In standard soil tests, this bound $\mathrm{P}$ is often detected as available and yet cranberry samples taken from beds testing high for soil $\mathrm{P}$ are often low or deficient in tissue P (Davenport et al., 2009). Growers add P fertilizer to increase tissue test $\mathrm{P}$. Yet the question remains: Does the addition of $\mathrm{P}$ fertilizer increase cranberry yield when tissue $\mathrm{P}$ is in the sufficient range?

In a study of $\mathrm{P}$ rates in Massachusetts, on beds testing sufficient for tissue $\mathrm{P}$, yield in plots receiving $\mathrm{P}$ fertilizer was significantly greater than that in untreated control plots (DeMoranville and Davenport, 1997), but there were no significant differences among any of the applied rates (20-60 lb/acre P). Rates below $20 \mathrm{lb} /$ acre were not included in that study. A later study in Wisconsin and Massachusetts (Roper, 2009) looked at P rates of $5,10,15,20$, and $30 \mathrm{lb} /$ acre. In Wisconsin, there was no response to $\mathrm{P}$ fertilizer on either sand or peat soils; only after 6 years did the untreated control plots show tissue $\mathrm{P}$ slightly below the sufficient range. In Massachusetts, where tissue test $\mathrm{P}$ in the plot sites was initially lower than that in the Wisconsin sites, there was a modest yield response to $15-20 \mathrm{lb} /$ acre $\mathrm{P}$ in 1 of the 5 years of the study; in the other years there was no yield response to applied P. Clearly the recommendation not to exceed $20 \mathrm{lb} /$ acre $\mathrm{P}$ in the absence of a documented deficiency (DeMoranville, 2014a) is supported by these data.

\section{Cranberry nutrient management and water quality concerns}

Nitrogen (coastal waters) and $\mathrm{P}$ (inland lakes) enrichment have been implicated in degradation of water resources. Since cranberry production is heavily dependent on water use, the interaction of nutrient management, particularly for $\mathrm{N}$ and $\mathrm{P}$, and water management has become a primary focus area for research and extension. Potassium interactions with water management have not been studied as $\mathrm{K}$ is not generally considered an environmental pollutant. Cranberry production activities, including irrigation, harvest flooding, and flooding to protect from winter dehydration, can use up to 10 acre- $\mathrm{ft}$ of water per year (DeMoranville, 2008b) and cranberry water permits in Massachusetts are issued on that basis. Because such large volumes are involved, even small concentrations of $\mathrm{N}$ or $\mathrm{P}$ in the water can result in substantial discharges. In a study of a single cranberry bog system (Howes and Teal, 1995), the annual nutrient budget showed a calculated $\mathrm{N}$ discharge of $22 \mathrm{~kg} \cdot \mathrm{ha}^{-1}$ per year and a P discharge of $9.9 \mathrm{~kg} \cdot \mathrm{ha}^{-1}$ per year.

Spurred by increasing environmental pressure regarding the protection of surface water resources from excessive P loading, Massachusetts cranberry growers were enlisted in a demonstration project (DeMoranville, $2014 \mathrm{~b}$ ) and agreed to reduce their annual $\mathrm{P}$ use to substantially less than the maximum recommendation of $20 \mathrm{lb} /$ acre. Regression analysis of data from seven sites participating from 2005 to 2011 showed a nonsignificant relationship between applied $\mathrm{P}$ rate and yield in that year. Variability in yield could most likely be attributed instead to variable $\mathrm{N}$ rates and cultivar differences among the sites. It was notable that the highest yielding site/years were associated with $P$ rates of 5-10 lb/acre. At one site, the longest participating site in the group, an average of $10 \mathrm{lb} /$ acre $\mathrm{P}$ was implemented beginning in 2003 . Figure 1 shows that during the period from 2003 to 2014 , yield has been variable but greater than that from 2000 to 2002, when the grower had been using an average of $20 \mathrm{lb} /$ acre $\mathrm{P}$ for several years. The exception was 2010 , a year when the crop was impacted by frost damage. That very small crop resulted in exaggerating the biennial tendencies (Strik et al., 1991) of the cranberry plants. The outcome was a very large crop in 2011 followed by a small crop in 2012. By 2013-14, the yield swings had leveled out and yield returned to a similar level as that in 2008-09 before the frost loss. But with recommended P application rates already low, why undertake this $P$ reduction at all?

DeMoranville and Howes (2005) examined six cranberry bogs, including older peat-based bogs and more recent, sand-based plantings, to develop partial nutrient budgets for $\mathrm{N}$ and $\mathrm{P}$ (focusing primarily on the flood activities and their large water volumes). Table 2 shows the range of $\mathrm{P}$ export calculated for those bogs; Table 3 shows the data for $\mathrm{N}$. The cranberry bog in the Howes and Teal (1995) study was a configuration known as a "flow-through" bog system (i.e., a planted area with a stream running through it). In contrast, the six cranberry bogs shown in Tables 2 and 3

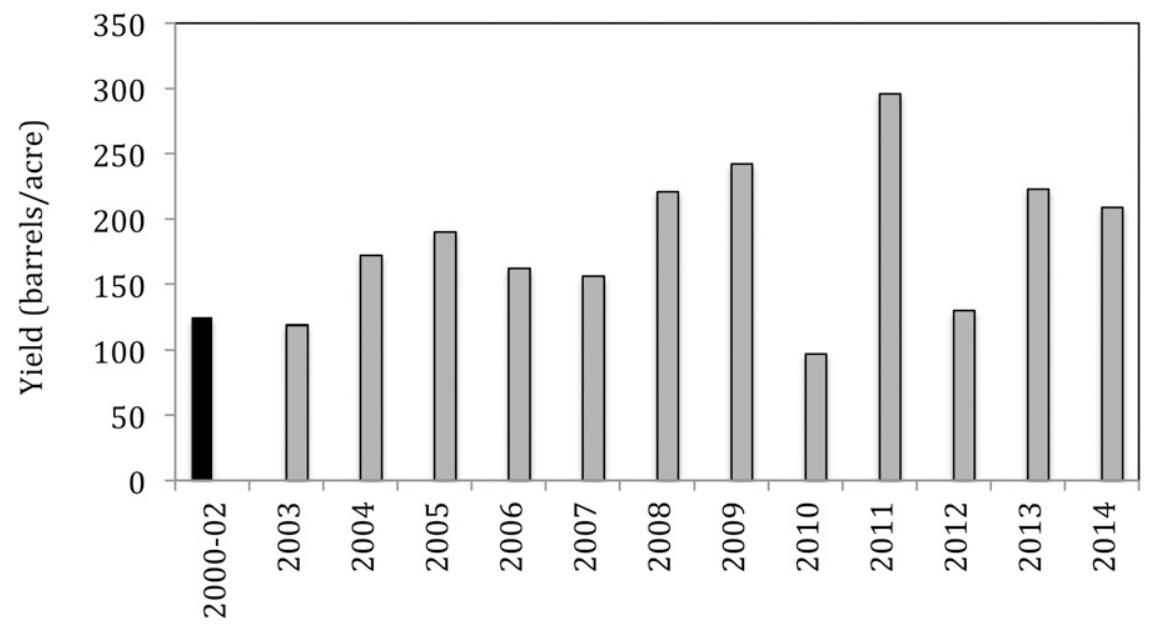

Fig. 1. Cranberry yield at a commercial site in southeastern Massachusetts calculated from the grower's delivery receipts. In 2010, frost damage reduced yield dramatically leading to exaggerated biennial yield trends in the following 2 years. By 2013-14, yield swings had leveled out. The black bar is the mean of 2000-02, years in which the grower applied an average of $20 \mathrm{lb} /$ acre phosphorus $(P)$ per year; the gray bars are years in which the grower applied an average of $10 \mathrm{lb} /$ acre $P$ per year; $1 \mathrm{lb} / \mathrm{acre}=1.1209 \mathrm{~kg} \cdot \mathrm{ha}^{-1}, 1100-\mathrm{lb}(45.4 \mathrm{~kg})$ barrel $/$ acre $=112.0851$ $\mathrm{kg} \cdot \mathrm{ha}^{-1}$. 
Table 2. Mean annual total phosphorus (TP) export in drainage water and annual applied phosphorus (P) for six Massachusetts cranberry bogs in 2003-04. The first four sites were older, peat-based beds, the last two were new plantings in sand.

\begin{tabular}{lcccc}
\hline $\begin{array}{l}\text { Bog } \\
\text { identifier }\end{array}$ & $\begin{array}{c}\text { P applied in } \\
\text { fertilizer }\end{array}$ & $\begin{array}{c}\text { TP incoming } \\
\text { in applied water }\end{array}$ & $\begin{array}{c}\text { TP leaving in } \\
\text { discharge water }\end{array}$ & $\begin{array}{c}\text { Net TP export } \\
\text { in water }\end{array}$ \\
\cline { 2 - 5 } (lb/acre per $\mathbf{~ y r ) ~})^{\mathbf{z}}$ & \multicolumn{2}{c}{ (lb } & \\
EH & 10 & 0.27 & 4.01 & 3.74 \\
PV & 20 & 1.61 & 7.58 & 5.97 \\
BEN & 17 & 1.07 & 3.48 & 2.41 \\
WS & 18 & 0.18 & 4.91 & 4.73 \\
M-K & 21 & 1.78 & 2.85 & 1.07 \\
ASH & 35 & 1.61 & 3.03 & 1.42 \\
\hline
\end{tabular}

${ }^{2} 1 \mathrm{lb} / \mathrm{acre}=1.1209 \mathrm{~kg} \cdot \mathrm{ha}{ }^{-1}$.

Table 3. Mean annual total nitrogen (TN) export in drainage water and annual applied nitrogen (N) for six Massachusetts cranberry bogs in 2003-04. The first four sites were older, peat-based beds, the last two were new plantings in sand.

\begin{tabular}{lcccc}
\hline \multirow{2}{*}{$\begin{array}{l}\text { Bog } \\
\text { identifier }\end{array}$} & $\begin{array}{c}\text { N applied in } \\
\text { fertilizer }\end{array}$ & $\begin{array}{c}\text { TN incoming } \\
\text { in applied water }\end{array}$ & $\begin{array}{c}\text { TN leaving in } \\
\text { discharge water }\end{array}$ & $\begin{array}{c}\text { Net TN export } \\
\text { in water }\end{array}$ \\
\cline { 2 - 5 } (lb/acre per $\mathbf{~} \mathbf{r})^{\mathbf{z}}$ & \\
EH & 35 & 5.5 & 11.8 & 6.3 \\
PV & 39 & 10.5 & 16.5 & 6.0 \\
BEN & 32 & 12.8 & 26.2 & 13.4 \\
WS & 32 & 3.7 & 8.8 & 5.1 \\
M-K & 44 & 12.4 & 16.1 & 3.7 \\
ASH & 44 & 11.4 & 15.2 & 3.8 \\
\hline
\end{tabular}

${ }^{\mathrm{z}} \mathrm{l} \mathrm{lb} / \mathrm{acre}=\mathrm{kg} \cdot \mathrm{ha}^{-1}$.

did not have a constant flow of water; most water discharges in those systems were associated with flood releases. At all six sites, the calculated $\mathrm{N}$ and $\mathrm{P}$ discharges were lower than those calculated in the previous study ( $\approx 20 \mathrm{lb} /$ acre $\mathrm{N}$ and $8.83 \mathrm{lb} /$ acre $\mathrm{P})$. However, measurable amounts of $\mathrm{N}$ and $\mathrm{P}$ are leaving the bog systems. Interestingly, the two bogs that had been recently constructed on sand averaged $3.8 \mathrm{lb} /$ acre $\mathrm{N}$ and 1.25 $\mathrm{lb} /$ acre $\mathrm{P}$ export compared with the average for the four bogs on older peat-based media, $7.7 \mathrm{lb} /$ acre $\mathrm{N}$ and $4.21 \mathrm{lb} /$ acre $\mathrm{P}$ export. An extensive study of water leaving cranberry beds during floods (C. Kennedy, P. Kleinman, and C. DeMoranville, unpublished data) found that $P$ export was lowest in a recently renovated cranberry bed compared with nonrenovated beds. The renovated bed had been top-dressed with a fresh layer of sand before replanting. In the early years of a new cranberry planting or renovation, the surface layer of sand may provide more capacity to bind $\mathrm{P}$ compared with an older bed where legacy $\mathrm{P}$ applications may have saturated that capacity. In regard to $\mathrm{N}$, older beds may have accumulations of dissolved organic $\mathrm{N}$ that could be subject to export during flood releases. These speculations are the hypotheses being addressed in this research.

Many small lakes and ponds in southeastern Massachusetts, some associated with cranberry bogs, are on the list of impaired waters of the state due to $\mathrm{P}$ enrichment. One of those, White Island Pond, has had a TMDL issued by the Massachusetts Department of Environmental Protection (MassDEP, 2012). The pond has two cranberry farms at its north end; both use the pond as a water source for flooding and irrigation. Under the directives of the TMDL, the cranberry farms must limit their $\mathrm{P}$ discharges to amounts approximating the average $\mathrm{P}$ in a winter flood discharge. Therefore, their harvest floods and any other water that might leave their farms cannot be returned to the pond. The growers have worked with MassDEP to devise strategies to avoid returning $\mathrm{P}$-containing flood waters to White Island Pond. One of the growers chose to sacrifice a 16.5-acre bed to be converted into a holding pond. With the creation of the holding pond, this grower now releases no water to White Island Pond. The other grower has identified an upland area where water is pumped in lieu of discharging to the pond. The water filters through the sandy soil and eventually moves downstream to the pond via groundwater flow. In one case, a production bed was sacrificed, in the other a very expensive pumping operation was established. Both are very costly choices. The question that arises: Can we find a less costly management practice that decreases P leaving the farm in floodwater?

This brings us back to the growers who, as cooperators in our demonstrations studies, have reduced $P$ fertilizer use. Water samples of the harvest and winter floods on those farms have been collected each year and the $\mathrm{P}$ concentrations documented (DeMoranville, 2014b). Figure 2 shows the change in $\mathrm{P}$ concentrations in harvest and winter flood releases for the longest participating site. After 7 years reducing $\mathrm{P}$ fertilizer from 20 to $10 \mathrm{lb} /$ acre, $\mathrm{P}$ concentration in harvest flood release from that site had declined by $\approx 85 \%$. This is good evidence that significant improvement in water quality can be achieved simply by decreasing the use of $\mathrm{P}$ fertilizer. Lowering $\mathrm{P}$ inputs saves money and extensive plot-scale and field-scale research indicates that crop yield is not compromised. Future P research will focus on identifying the temporal scale functions of $\mathrm{P}$ discharge in flood releases, looking at how soil type and site hydrology interactions during flood releases impact $\mathrm{P}$ discharge, and in exploring filtration or other treatment of water discharged to particularly sensitive water bodies.

As noted above, the most extensive study of a cranberry farm to date (Howes and Teal, 1995) calculated annual $\mathrm{N}$ output from that cranberry farm to be $\approx 20 \mathrm{~kg} \cdot \mathrm{ha}^{-1}$. That has since been used in models of watershedwide $\mathrm{N}$ contributions to coastal estuaries in southeastern Massachusetts. Those estuaries have been listed on the Massachusetts impaired waters list as impaired by N. However, the flow-through style farm configuration in the Howes and Teal (1995) study represents $<15 \%$ of cranberry farms in southeastern Massachusetts (Buzzards Bay National Estuaries Program, 2003; L. Rinta, personal communication). The DeMoranville 


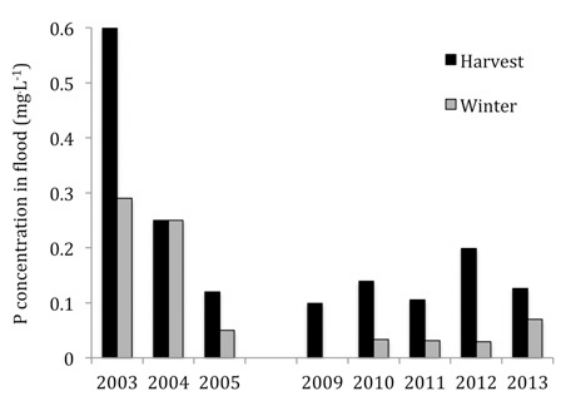

Fig. 2. Concentration of phosphorus $(P)$ in harvest (black bars) and winter (gray bars) flood releases. $P$ fertilizer was reduced from an average of $20 \mathrm{lb} /$ acre $P$ per year to an average of $10 \mathrm{lb} /$ acre $P$ per year beginning in 2003 , no water quality data were collected from 2006 to $2008 ; 1 \mathrm{lb} /$ acre $=1.1209$ $\mathrm{kg} \cdot \mathrm{ha}^{-1}, 1 \mathrm{mg} \cdot \mathrm{L}^{-1}=1 \mathrm{ppm}$.

and Howes (2005) six-bog study, with no flow-through style sites, found a range of $\mathrm{N}$ export from 3.7 to 13.4 $\mathrm{lb} /$ acre (Table 3 ).

Recent research, undertaken by a partnership among the Marine Biological Laboratory Ecosystems Center, the environmental nonprofit Coalition for Buzzard Bay, the UMass Cranberry Station, U.S. Department of Agriculture, and the Cape Cod Cranberry Growers Association, is examining additional cranberry farms with nonflowthrough configurations. Preliminary data indicate that the cranberry bogs may act as either a source or sink for $\mathrm{N}$ depending on configuration and management activities. The research also confirms the supposition that the $\mathrm{N}$ export pathway is predominantly in surface water. The groundwater pathway appears to be limited due to the natural or constructed barrier layers in cranberry soils that allow the impoundment of floods. The routine practice of applying $\mathrm{N}$ in the ammonium form (DeMoranville, 2014a) may also contribute to lack of leaching. One primary objective of this research into $\mathrm{N}$ export from cranberry bogs is to identify accurate, bog configuration-specific numbers that can be incorporated into the models of estuary $\mathrm{N}$ loading.

In the 21 st century, in Massachusetts, cranberry nutrient management, at least for $\mathrm{N}$ and $\mathrm{P}$, is also cranberry water management. As a result, research and extension efforts have become focused on the nexus of those practices and their implications not only for crop production, but also for potential water quality impacts. Of equal importance, as higher-yielding cultivars are planted, is research to identify optimum nutrient application rates that maximize their productivity and minimize off-site impacts. Future research should also focus on the factors that control nutrient mobilization in drainage and flood water, including the importance of soil types, site hydrology, nutrient application rates and forms, and water management activities.

\section{Literature cited}

Buzzards Bay National Estuary Program. 2003. Information about Cranberry Bogs and the Environment. 26 Mar. 2015. $<$ http://www.buzzardsbay.org/ craninfo.htm>.

Davenport, J., C. DeMoranville, J. Hart, K. Patten, L. Peterson, T. Planer, A. Poole, T. Roper, and J. Smith. 1995. Cranberry Tissue Testing for Producing Beds in North America. 26 Jan. 2015. $<$ http://scholarworks.umass.edu/ cranberry_factsheets $/ 6>$.

Davenport, J., C. DeMoranville, J. Hart, and T. Roper. 2000. Nitrogen for Bearing Cranberries in North America. 27 Mar. 2015. <http://ir.library.oregonstate. edu/xmlui/bitstream/handle/1957/ 20088/em8741.pdf>.

Davenport, J. and D. Horneck. 2011. Sampling Guide for Nutrient Assessment of Irrigated Vineyards in the Inland Pacific Northwest. Pacific Northwest Ext. Publ. PNW622. 28 Jan. 2015. <https:// pubs.wsu.edu/List Items.aspx? Keyword=PNW622>

Davenport, J.R. 1996. The effect of nitrogen fertilizer rates and timing on cranberry yield and fruit quality. J. Amer. Soc. Hort. Sci. 121:1089-1094.

Davenport, J.R., C. DeMoranville, and T. Roper. 2009. Evaluation of six different soil test phosphorus extraction methods for relationship with cranberry. Acta Hort. 810:627-632.

Davenport, J.R. and N. Vorsa. 1999. Cultivar fruiting and vegetative response to nitrogen fertilizer in cranberry. J. Amer. Soc. Hort. Sci. 124:90-93.

DeMoranville, C. 1992. Cranberry Nutrients, Phenology, and N-P-K Fertilization. Univ. Massachusetts, Amherst. PhD Diss. 26 Jan. 2015. <http:// scholarworks.umass.edu/dissertations/ AAI9305818>.

DeMoranville, C. 2008a. Properties of bog soil, p. 11-12. In: H. Sandler and
C. DeMoranville (eds.). Cranberry production: A guide for Massachusetts. 26 Jan. 2015. <http://scholarworks.umass. edu/cranberry_prod_guide/8>.

DeMoranville, C. 2008b. Water Use in Cranberry Production, p. 39-4l. In: H. Sandler and C. DeMoranville (eds.). Cranberry production: A guide for Massachusetts. 26 Jan. 2015. <http:// scholarworks.umass.edu/cranberry_ prod_guide $/ 8>$.

DeMoranville, C. 2014a. Nutrition, p. 47-57. In: M. Sylvia, D. Gauvin, and H. Sandler (eds.). Cranberry chart book management guide for Massachusetts. 26 Jan. 2015. <http://scholarworks.umass. edu/cranchart/186>.

DeMoranville, C. 2014b. Reducing phosphorus use in cranberry production: Horticultural and environmental implications. Acta Hort. 1017:447-453.

DeMoranville, C.J. and B.P. Howes. 2005. Phosphorus Dynamics in Cranberry Production Systems: Developing the Information Required for the TMDL Process for 303D Water Bodies Receiving Cranberry Bog Discharge. 27 Jan. 2015. $<$ http://scholarworks.umass.edu/ cranberry_research_repts/13>

DeMoranville, C.J. and J.R. Davenport. 1997. Phosphorus forms, rates, and timing in Massachusetts cranberry production. Acta Hort. 446:381-388.

Eaton, G.W. 1971. Effect of N, P, and K fertilizer applications on cranberry leaf nutrient composition, fruit color, and yield in a mature bog. J. Amer. Soc. Hort. Sci. 96:430-433.

Eaton, G.W. and C.N. Meehan. 1976. Effects of $\mathrm{N}$ and $\mathrm{K}$ applications on the leaf composition, yield, and fruit quality of bearing McFarlin cranberries. Can. J. Plant Sci. 56:107-110.

Hanson, E. 2014. Apple Nutrition. 28 Jan. 2015. <apples.msu.edu/uploads/ files/Applenutrition-EricHanson.pdf>.

Hart, J.M., A. Poole, K.L. Wilder, and B. C. Strik. 1990. Nitrogen rate and timing affect on cranberry yield and yield components. HortScience 25:1148 (abstr.).

Hart, J.M., B.C. Strik, C. DeMoranville, J.R. Davenport, and T. Roper. 2015. Cranberries, a Nutrient Management Guide for South Coastal Oregon. Oregon State Univ. Ext. Ser. Publ. EM8672. 27 Jan. 2015. <https://ir.library.oregonstate. edu/xmlui/bitstream/handle/1957/ 54896/em8672.pdf>.

Howes, B.L. and J.M. Teal. 1995. Nutrient balance of a Massachusetts cranberry bog and relationships to coastal eutrophication. Environ. Sci. Technol. 29:960-974. 


\section{Colloquium}

Massachusetts Department of Environmental Protection. 2012. Final total maximum daily load of total phosphorus for White Island Pond Plymouth/ Wareham, MA. TMDL Rpt. MA95166201009-1 CN330.2.27 Jan. 2015.<http:// www.mass.gov/eea/agencies/massdep/ water/watersheds/total592maximumdaily-loads-tmdls.html\#2>.

Roper, T.R. 1999. Cranberry cultivar acreage survey: Are we shunning genetic diversity? Cranberries 63(5):13-14.
Roper, T.R. 2009. Mineral nutrition of cranberry: What we know and what we thought we knew. Acta Hort. 810:613626.

Strik, B. 2013. Nutrient Management of Berry Crops in Oregon. 28 Jan. 2015. <www.oregon-strawberries.org/ attachments/2013-May_Nutrient_ Management_Berry_Crops_OSU.pdf>.

Strik, B.C., T.R. Roper, C.J. DeMoranville, J.R. Davenport, and A.P. Poole. 1991. Cultivar and growing region influence return bloom in cranberry uprights. HortScience 26:1366-1367.
U.S. Department of Agriculture. 2015. Noncitrus Fruits and Nuts, 2014 Preliminary Summary. 28 Jan. 2015. <usda. mannlib.cornell.edu/usda/current/ NoncFruiNu/NoncFruiNu-01-232015.pdf>.

Yarborough, D. and J. Smagula. 2013. Wild Blueberry Fact Sheet: Interpreting Your Leaf Analysis Results. Fact Sheet No. 223, Univ. Maine Ext. No. 2093. 28 Jan. 2015. <http://umaine.edu/blueberries/ factsheets/production/interpretingyour-leaf-analysis-results $/>$. 